\title{
Cities, networks, polycentrism - examining the place of polycentrism in spaces of flows
}

Book or Report Section

Accepted Version

Pain, K. and Shi, S. (2021) Cities, networks, polycentrism examining the place of polycentrism in spaces of flows. In: Neal, Z. P. and Rozenblat, C. (eds.) Handbook of Cities and Networks. Research Handbooks in Urban Studies series.

Edward Elgar, Cheltenham, pp. 493-510. ISBN 9781788114714 Available at https://centaur.reading.ac.uk/92903/

It is advisable to refer to the publisher's version if you intend to cite from the work. See Guidance on citing.

Publisher: Edward Elgar

All outputs in CentAUR are protected by Intellectual Property Rights law, including copyright law. Copyright and IPR is retained by the creators or other copyright holders. Terms and conditions for use of this material are defined in the End User Agreement. 


\section{CentAUR}

Central Archive at the University of Reading

Reading's research outputs online 
Cities, Networks, Polycentrism - Examining the place of polycentrism in spaces of flows

Kathy Pain, Department of Real Estate \& Planning, Henley Business School, University of Reading, United Kingdom

Shuai Shi, Department of Real Estate \& Planning, Henley Business School, University of Reading, United Kingdom

Abstract

In a globalising world economy, cities have increasingly come to be defined not by their size in terms of built up area or population but by their functions in the networks constructed by cross-territorial capital flows. In contemporary inter-city networks, city regions are differentiated not only by their physical pattern of urban development but also by their functional pattern in network space. However, the concept of city region 'polycentrism' has commonly referred to morphological space without paying due regard to network space, functions and flows. This paper dissects the concept of polycentrism by examining interrelationships and distinctions between city region network and morphological space development in mature and developing economy contexts with reference to research conducted in South East England and in the Mid-Yangtze River region, China. It is concluded that a more progressive definition of polycentrism is needed to inform coordinated strategic city region policy.

Key words

City networks / Polycentrism / Morphological space / Network space / Functional city region / Polycentric urban region

\section{Introduction Level 1}

In a globalising world economy, cities have increasingly come to be defined not by their size in terms of built up area or population but by their functions in networks that connect them to capital flows that cross territorial boundaries (Rozenblat, 2010). As Sassen (1991) put it in her 'global cities' thesis, "massive trends toward spatial dispersion of economic activities at the metropolitan, national and global level, which we associate with globalisation, have contributed to a demand for new forms of territorial centralisation of top-level management and control operations". As the centralities for management and control functions in network enterprises operating at different spatial scales, globalising cities can be expected to be economically vibrant due to their role in facilitating the circulation and accumulation of intellectual and financial capital. Moreover, according to protagonists of Jacobs (1984), the vibrancy of such cities spills over metropolitan boundaries to form prosperous globalising city regions (Scott, 2001a, b; Hall and Pain, 2006). A new paradigm of city networks, functions and flows has therefore come to overtake the traditional paradigm of places and territorial borders as the structure of the contemporary global space economy. 
In the networked economy that has been evolving for half a century, it follows that city regions are differentiated not only by their physical pattern of urban development but also by their functional pattern in network space. In consequence, city region spatial form (morphology) and city region 'Jacobsean' economic expansion, while interrelated, are distinctive development processes that should not be confused, the one with the other (Taylor and Pain, 2004; Pain, 2012). However, the concept of 'polycentrism' has referred to morphological space without paying due regard to network space, functions and flows, for almost two decades in policy to rebalance uneven regional economic development in Europe (European Commission, 1999; Davoudi, 2004; Duhr et al., 2005; Halbert et al., 2006; Pain, 2008). Thus, European spatial planning strategy has promoted the development of 'polycentric urban regions' (PURs) based on examples of regions populated by many similar sized urban centres, such as the Randstad region in the Netherlands, and the Rhine-Ruhr region in Germany, which are regarded as a superior spatial form to 'monocentric' regions dominated by one centre such as South East England and the French Paris region.

In this paper we argue for a more progressive definition of polycentrism that is informed by city region network space patterns and how these map onto morphological space. Since capital and labour have continued to migrate to rapidly enlarging world cities that are new bases of the capitalist economy in twenty first century economic globalisation, governments worldwide have looked to European policy on polycentrism to counter emerging regional development imbalances. Shedding fresh light on the concept of polycentrism has therefore, we argue, come to have more, not less, importance over time. Accordingly, in this paper, we attempt to dissect the concept of polycentrism by examining interrelationships and distinctions between city region network and morphological space development in mature and developing economy contexts. We address two questions: First, can attention to city network space, functions and flows, usefully inform conceptualisation of city region polycentrism; and, second, how should the concept of polycentrism inform planning policies in the context of city regions that are at different stages of connecting to economic globalisation?

In order to shed light on these hitherto under-researched questions, evidence from two city region cases will be drawn on in the paper: the South East England city region in the densely urbanised and economically developed North Western Europe context and the Mid-Yangtze River city region in the rapidly urbanising and developing economy context of China. The paper first introduces the two city regions and their distinctive development contexts. Second, the concept of the city network in a globalising world economy, its relevance for the Jacobsean economic expansion process, and for polycentrism are considered. Third, the network approach to regional analysis is explained, some common methodologies for the investigation of inter-city network flows and the rationale behind different analytical approaches adopted in the case studies due to their distinctive development stages are outlined. Fourth, the findings from the North West European study are reviewed before turning to 
consider evidence on recent city region emergence in the Chinese case. Finally, distinctions between city region economic expansion processes and polycentrism revealed by network space analysis in the two cases are reviewed and the general implications for reference to polycentrism in planning policies are considered. It is concluded that the concept of polycentrism can only have relevance for policy to foster economic rebalancing when a theory of city region space as an artefact of city networks is taken into account.

Introducing the Case Studies - The South East England and Mid-Yangtze River City Regions Level 1

The South East England case study was undertaken as part of a larger 2003-06 research project conducted in eight North West European city regions to inform European Union (EU) policy on polycentrism aiming to rebalance the European space economy and at the same time increase Europe's economic competitiveness in a global context (European Council, 2000; European Commission, 2004, 2009; Hall and Pain, 2006; Pain and Hall, 2008) ${ }^{1}$ : the Randstad, Netherlands; Central Belgium; Northern Switzerland; Rhine-Main and Rhine-Ruhr, Germany; Paris Region, France; Greater Dublin, Ireland; and South East England (Hall and Pain, 2006; Pain and Hall, 2008). North Western Europe is one of the most urbanised and economically developed regions in the world, where city regions have become a prevailing urban form. The research was the first in the world to draw on Scott's (2001a) global city region thesis to examine polycentrism using a network analysis lens. South East England was selected for study due to its apparent monocentrism compared to The Randstad, Netherlands and the Rhine-Ruhr, Germany for example. South East England's primary city, London, is the most connected city in the world to dominant advanced producer services sectors and is referred to in European spatial policy as a 'global gateway' city (European Commission, 1999; Duhr et al., 2005) potentially capable of generating economically value-adding flows to peripheral regions with increased connectivity in the form of trans-European transportation networks (TENs) such as high-speed rail. It is therefore seen as important for Europe's global competitiveness but also a source of economic vibrancy that that can contribute to rebalancing development from the European 'core' to 'peripheral' economies (Wallerstein, 1974; Friedmann, 1986).

Located in central China, the Mid-Yangtze River region was selected ten years after the South East England research as a 2014-17 study ${ }^{2}$ because, unlike the Yangtze River Delta city region that

\footnotetext{
1 'POLYNET: Sustainable Management of European Polycentric Mega-City Regions' led by Peter Hall and Kathy Pain at the Young Foundation, London, was a three year research project funded by European Regional Development Fund that examined changes in functional connections and information flows in eight major city regions across North West Europe.

${ }^{2}$ The study 'The Convergence of Geo-space and Network Space in City Region Development in China: taking the Mid-Yangtze River City Region as an example' has been granted the award of $\mathrm{PhD}$ in the Department of Real Estate \& Planning at the University of Reading, UK.
} 
encompasses Shanghai or the Jing Jin Ji city region that encompasses Beijing, the Mid-Yangtze River city region is seen in Chinese national spatial planning policy as rebalancing development between the coastal and the non-coastal inland regions, which is a national priority to reduce growing economic and social inequity associated with opening China up to globalisation. In particular, along with rising labour costs, competition from other emerging economies, and recent global economic malaise, China initiated a crucial transition period from a labour-intensive and capital-driven economy to a more advanced and potentially resilient economy by the expansion of added-value activities. The Mid-Yangtze River city region is thereby identified as a strategic growth region ('growth pole') in China's economic transition due to its established industrial base, well-developed infrastructure system, developed higher education, well-qualified labour etc., and its geographical location, which are seen as making it a conduit between the east and the west. As in the South East England case, the Mid-Yangtze River study draws on Scott's (2001a) global city region discourse and employs a series of network analysis methods to shed light on emergent city network patterns in the process of regional development. However, in contrast to developed South East England, the Mid-Yangtze River city region is a developing inland region in the context of China's rapid urbanisation and economic transition. The contrasting characteristics of the case study city regions enriches the discussion of progressive polycentrism.

\section{City networks in a globalising world economy Level 1}

In the globalising world, complex urban processes significant for economic development emerge from relations and flows between cities with few spatial constraints. In city network space, economic growth is increasingly associated with connectivity to the 'space of flows' facilitated by advances in informational and communications technologies (ICT) and structured by the circulation of virtual flows of information, finance etc. (Ohmae, 1990, 1995; Castells, 1996; Rozenblat and Pflieger, 2010). However, local development outcomes in city networks remain intrinsically related to physical (geospatial) proximity, yet few studies have investigated the associations between network connectivity and flows, and spatial proximity that shape the space economy of city regions and fewer still have considered the implications of the interplay between inter-city network processes and spatial proximity for city region polycentricism.

\section{City region economic development in inter-city networks Level 2}

The rationale behind the argument for the influence of geo-spatial proximity on economic development reflects the so-called 'first law of geography' articulated by Tobler (1970 p. 234) as "everything is related to everything else, but near things are more related than distant things". Contradicting 'the end of geography' associated with increasing global financial integration (O'Brien, 1992), according to this geo-spatial logic, distance remains a key determinant of economic location 
because overcoming spatial constraints consumes energy and financial resources (Miller, 2004). Thus, urban places that are physically close (proximate) to each other should be expected to have intensive functional interactions, for example in employment and labour markets, that are advantaged by timecost reductions, for example, travel to work and business travel, which will, in turn, shape the pattern of regional development as an outcome. Furthermore, spatial proximity is emphasised in 'New Economic Geography' (Puga, 1999; Fujita et al., 2001) and endogenous growth theories (Aghion and Howitt, 1997) as a significant driver of economic growth. Further, it is argued that economic actors that are clustered in close physical proximity have access to flows of privileged information and knowledge transfer, and benefit from co-learning associated with agglomeration economies (Boschma, 2004).

This geo-spatial proximity rationale appears at first sight to contrast with that of city network theory which emphasises that in the context of globalisation, technological developments reduce the cost of overcoming spatial constraints to a substantial degree. In particular, the rise of the knowledge economy is argued by 'globalists' (Cochrane and Pain, 2000) to generate intensive virtual flows. Information, specialised knowledge and financialised capital associated with the activities of "new economy' knowledge intensive cross-border financial and linked business network enterprises (Wood, 1991) known as advanced producer services (APS), are subject to few spatial constraints. As Castells (1999, p.295) claimed, urban spaces have become the 'material arrangements' allowing for "simultaneity of social practices without territorial contiguity". He asserted that 'new economy' activity and specifically APS office network flows, transcend the 'space of places' and that in the present 'network society' trans-boundary flows of products, services, labour and knowledge, interconnect cities and markets regardless of territorially defined place boundaries (Pain and Van Hamme, 2014; Lizieri and Pain, 2014; Coe and Yeung, 2015). Resultant synergies between cities (Massey et al., 1999) indicate that a purely geo-spatial explanation of economic development based on city physical proximity, presents a partial view; contemporary urban spatial relations which are now also characterised by complex virtual flows must also be taken into account. Distinctively, this paper considers the congruence of urban geo-spatial distance and urban economic function-related inter-city network flows in developed and developing city region contexts to shed light on the question of polycentrism.

\section{The polycentric city region in network space Level 2}

The city region scale of analysis provides valuable insights into the normative relevance and practical utility of the concept of polycentrism as a spatial planning tool to address uneven development. In Europe, associated with enlargement and political ambitions for 'territorial cohesion' based on the French principle of 'aménagement du territoire', polycentrism has been actively promoted as a policy objective throughout the European urban system (European Commission, 1999, 2005, 2008, 2012). 
As applied in European spatial strategy, the term polycentricity has referred to the outward diffusion of development from major commercial cores and metropolises to smaller cities in order to rebalance the uneven distribution of urban assets at city, regional, national and EU wide scales (Davoudi, 2004; Hall and Pain, 2006). "Mega-city regions are a series of anything between 10 and 50 cities and towns physically separated but functionally networked, clustered around one or more larger central cities, and drawing enormous economic strength from a new functional division of labour" (Hall and Pain, 2006). Polycentrism thereby refers implicitly to the spatial arrangement of economic development and thus to the convergence of physical proximity and network distance implied by the geo-spatial and network space theoretical rationales.

\section{As Watts (1999) put it in Small Worlds: The Dynamics of Networks - Between Order and}

Randomness, 'near' (proximate) and 'distant' can interact to create complex city network interconnections and these interconnections are particularly relevant for city region development. As Scott (2001a, p18) noted, "global city-regions come to function increasingly as the motors of global economy, as dynamic local networks of economic relationships caught up in more extended worldwide webs of interregional competition and exchange". It is argued in this paper that understanding local (near) and distant (worldwide) interactions by adopting a network approach to city region analysis can therefore shed valuable light on the interrelationship between functional and geo-spatial development processes, uneven development and polycentrism.

\section{Unravelling the concept of functional polycentrism Level 2}

As Duranton and Puga (2001) argued, cities are increasingly recognised by their economic functions and it is the spatial patterns associated with the functional relations between cities in city networks that are the prime interest of this paper. As first identified in Harris and Ullman's (1945) multiple nuclei model, a polycentric urban development pattern is characterised by numerous urban centres of similar size however as already discussed, city business network functional locations and exchanges of people, goods and information that define 'functional polycentricity' as opposed to 'morphological polycentricity' is critically important for space economy vitality at a city region scale. Later, Van Oort (2010) argued that, "The outcome of functional polycentricity is a considerable regional cohesion in personal, occupational and corporate relationships of people, organisations and firms that transcends the boundaries of the traditional metropolitan areas.” (p. 726). Therefore, the pursuit of polycentrism in spatial planning policy demands a reconfiguring of the city region urban hierarchy (Christaller, 1966 (1933)) with urban service functions dispersed out from higher-order central cities to lowerorder cities to reshape the 'space of places'. However, accomplishing this aim in the contemporary world of city networks is dependent on Castells' (1996) 'space of flows'. 
Globalisation and the rise of the knowledge economy have transformed contemporary physical urban spaces into data factories where circulating labour, capital, information, commodities and human flows generate ideas, innovations, knowledge, entrepreneurships etc. that facilitate urban growth as an outcome. In addition to the massive scale and intensity of these flows, they are distinctive in terms of their content, quality, value-added, distance, and directional and temporal characteristics in different local contexts. The heterogeneity of city network flows is reflected in the characteristics of the local spaces where globalisation hits the ground. Meanwhile, the circulation of large-scale heterogeneous flows gives rise to inter-city networks in which cities have different structural positions and network roles (such as a commanding role or a broker role). In other words, the circulation of heterogeneous flows, results in local spaces also characterised by heterogeneity in the form of diverse city network functions and positions and development dynamics which must inform the issue of city region polycentrism. The South East England and MYR city region different case settings - the former characterised by APS sectors identified by Friedmann (1986), Sassen (1991) and Castells (1996) as the drivers of a thriving knowledge economy versus the latter characterised predominantly by labourintensive manufacturing - allow polycentrism to be considered in relation to economic transition from a capital driven to a knowledge-based economy.

\section{City Networks as a Lens for Revealing City Region Polycentrism Level 1}

With ICT technology breakthroughs and the development of high speed modern transportation, the spatial constraints on inter-city flows and relations in economic activities have been much reduced (Friedmann, 2005). The rise of the knowledge based advanced service economy has generated intense virtual flows, capital mobility, knowledge exchange and information sharing that are dynamically interconnecting cities across territorial boundaries worldwide. Therefore, while the network argument relates to central place theory (Taylor, 2009), the two theories, the Christallerian hierarchy and the concept of urban networks, are contraposed. Central place theory and Harris and Ullman's view of 'the nature of cities' (1945) which focused on hierarchical centre-hinterland relations have become less relevant to the reality of how the space economy maps onto city regions under the influence of globalisation. As Taylor et al (2010) argued, central place thinking emphasises external urban relations as a local-hinterland process whereas city network thinking recognises urban relations as a non-local city flow process. A network lens is thereby required to complement central place theory in the analysis of the functional polycentrism of city regions with distant as well as local economic relations.

The city network approach - Some theoretical reflections Level 2

In fact, as early as 1964, Berry claimed that urban geography essentially focused on 'cities as systems within systems of cities' (Berry, 1964), highlighting the need to look at the relations between cities in 
a network perspective that pays due regard to complementary urban functions and synergistic business links. In contrast to the emphasis on the local industrial base in competitiveness theory, Burt (2009) illustrated that competition is essentially a relationships issue as opposed to a competition between cities themselves and this observation has been supported by interviews with APS business actors based on a city network approach (Taylor et al, 2003; Hoyler and Pain, 2004). Meijers (2007) also found that the connections between cities tend to be more complementary than competitive in order to take advantage of scale economies, knowledge exchange and synergies. Meijers (2007) further explained that horizontal links allow collaboration while vertical links generate complementarities. Thus, it is argued by numerous authors that establishing inter-city connections is important for urban actors to develop cooperative business connections, to absorb external knowledge and to boost innovation and regional productivity as an outcome (Hakansson, 1987; Powell et al., 1996; Nicolini et al., 2003; Taylor et al., 2003; Bathelt et al., 2004; Mahroum et al., 2008; Breschi and Lenzi, 2014; Huggins and Thompson, 2015).

The importance of spatial proximity for business connections is reflected in the significance for headquarters location decisions of access to deep infrastructure that includes an array of specialised business services suppliers, labour and skills, and international air connectivity between cities (Button, 1999; Taylor et al., 2003; Bel and Fageda, 2008; Grubesic et al., 2008). According to Meijers (2007), simultaneous vertical and horizontal network links shape urban development processes because horizontal links allow collaboration while vertical links generate complementarities.

The New Economic Geography highlighted the significance of relations between cities in shedding light on urban space economy patterns (Krugman, 1991; Fujita et al., 2001) however the focus is mainly on the effects of spatial proximity and the local embeddedness of economic activities, focusing particularly on trade costs and market access (Redding and Venables, 2004). New Economic Geography perspectives have not paid attention to the multi-directionality and borderless characteristics of inter-city flows in a network context. To address the void of analysis of intangible networks constructed by multidirectional, borderless flows, the notion of 'calculative' network capital is proposed by some authors as a means of pinning down network outcomes in corporate interactions (Huggins, 2010; Huggins and Johnston, 2010; Kramer et al., 2011; Smith et al., 2012), which provides an avenue for inter-city network analysis. The notion of 'calculative' network capital argues that such capital is embedded in functional positions that are determined by network node (city) multidirectional 'ties' or links, and the attributes of those links. It is argued that a network is not only a structure but is also a source of strategic capital which can generate opportunities and constraints for city network actors. This understanding of city networks supports Bathelt and Taylor's (2002) assertion that a city's strategic network position is not only an indicator of economic performance but 
is also an important endogenous factor driving economic development. According to Jacobsean logic, this economic development can spill over to proximate urban places and we argue here, that this may generate 'functional polycentrism' at the city region scale.

\section{Common methodologies for the investigation of inter-city network flows Level 2}

There are several ways of investigating inter-city flow networks and their contribution to economic growth and regional development methodologically. Three common approaches are Global Production Network, Interlocking Office Network and Social Network Analysis. Resonating with Global Value Chain (GVC) theory, in Global Production Network analysis, territories are seen as integrated transnationally through value-added production processes (from decision-making, design, production, distribution, through to sales and services) that have functional production location outcomes in a globalised economy. Actors are theorised in the Global Production Network framework not as individual agents per se, but as a constitutive part of the wider network. The approach focuses on intra-firm chained linkages that add value to final products, thereby reflecting a microeconomic industrial production perspective. In contrast, the present paper is concerned with how flows in city networks influence city region development and their relevance for polycentrism. Thus, the case studies selected for examination here used other network analysis approaches chosen to suit their different development stages in economic globalisation: the Interlocking Office Network model approach in South East England and the Social Network Analysis approach in the Mid-Yangtze River region.

Taylor's Interlocking Office Network model employed in World City Network analysis (Beaverstock et al., 1999; Taylor, 2001a, 2004; Taylor et al., 2002) is based on Friedmann's (1986) world city hypothesis which emphasised functionality and big cities' commanding roles in a world city hierarchy and Sassen's (1991) global city theory which emphasised the significance of APS sectors with high value-adding activities in forming global cities which have outstanding connectivity (Castells, 1996). Since APS firms need to provide specialised services to clients, they require access and closeness to skilled labour pools, information-rich and prestigious environs, superior offices, and transport and telecommunications infrastructures, all of which are predominantly found in big cities (Harrington and Campbell, 1997); second, APS firms have formed their own global service networks as a new force amongst MNCs (Moulaert and Daniels, 1991; Aharoni and Nachum, 2002; Harrington and Daniels, 2006; Derudder et al., 2010). Essentially, as Scott (2001a, b) argued, the concentrated service functions in global cities not only represent the geography of powerful command positions in the global economy but they disseminate their power to counterparts through their international operations, and they are thereby indicators of the presence of 'vibrant' metropolitan economies. 
Drawing on Social Network Analysis, the Interlocking Office Network model uses data on office functions in five APS network sectors - banking/finance, accountancy, law, advertising, and management consulting - to map the interlinkages between cities based on the assumption that the strength of inter-city work flows is determined by organisational network office functions headquarters, regional offices, local offices, and back offices (Taylor, 2001a; Taylor et al., 2002; Taylor, 2004; Derudder and Taylor, 2016). Computing the strategic importance of cities in all APS networks provides service values of cities hosting APS clusters as an approximation of inter-city relations and thereby city network structures, revealing otherwise invisible patterns of city connectivity that are an outcome of the dual spatial dynamic of office dispersal and concentration (Sassen, 1991) and that generate inter-city networks.

In contrast to conventional statistical analysis, Social Network Analysis which underpins the Interlocking Office Network approach, is theoretically rooted in sociological enquiry that looks into the patterns of relationships between social actors. Associated with globalisation and the advent of the information age, myriad actors are involved in relations interlinking them in complex and heterogeneous ways, which allows the realm of Social Network Analysis to be extended to complex social systems at flexible scales, from the interpersonal to the international. The approach is therefore scale-free, which is advantageous in analysing multidirectional city interactions including functional polycentrism. Furthermore, intertwined with the rapid development of computing technology, the visualization of social networks becomes a powerful tool for conveying complex information using graph theory. In the World City Network approach, the network has three levels: APS firms are the economic actors in the network, the cities they use in their international operations are the nodes in the network and the world economy constitutes the supra-nodal network level. The actual global strategies of the firms that are operationalised through the nodes (cities) in which they have offices, generate the interlocking World City Network (Taylor, 2001).

Rationale behind different analytical approaches adopted in the two case studies Level 2

The use of inter-city APS office networks as a proxy for city network connectivity as opposed to actual inter-city flows between cities has been subject to critical debate (see for example, Nordlund, 2004) so in the North West European study of polycentrism in which South East England was one of eight city region cases, additional data on daily travel to work flows, virtual flows of information (email, phone, electronic) and face-to-face knowledge exchange within and between offices and locations were used alongside Interlocking Office Network analysis (Pain and Hall, 2008). First, the functionally defined city region encompassing all the areas having regular daily relationships based on commuting flows was analysed. Second, polycentric patterns were revealed using an Interlocking Office Network approach. Quantitative data on the office locations and importance of APS firms operating at the city region, national, European and global scales were collected to identify regional 
inter-city network functional relations (Taylor, 2004; Taylor et al., 2010). Third, questionnaires were used to collect data on APS firms' patterns of virtual communication to identify associated information flows (Pain and Hall, 2006). Fourth, 600 in-depth interviews with senior APS actors were used to elicit data on the quality and intensity of relations between city region-located offices and others in their national, European and global networks as a proxy for the quality and intensity of intercity flows and relations.

A pragmatic problem for the Mid-Yangtze River case study research was that APS are not sufficiently representative of its city economic structures which are undergoing early stage economic transition to new economy enterprise in globalisation. Manufacturing remains the predominant industry and, in consequence, data on APS sectors at the firm level, are neither available nor relevant metrics. At the empirically 'fuzzy end' of the World City Network (Markusen, 2003), inter-city flows more directly representative of functional polycentrism were direct inter-city capital flows in Mergers \& Acquisitions (M\&A) activities. Firstly, M\&A deals involve large capital flows that are free from spatial constraints, resonating with Castells' (1996) 'space of flows' theory. Secondly, in contrast to one-off trade deals, M\&A deals are characterised by control transfer and long-term interactions. Thirdly, M\&A deals are characterised by intensive interactions and valuable spillovers such as information exchange, technique sharing, elite communications and management learning (Freeman, 2004). Fourthly, M\&A deals not only operate between target and acquirer companies but are also an important component of APS activity, involving in particular financial and legal services, resonating with Sassen's (1991) global city theory. In network space, M\&A projects explicitly reflect both longterm elite interactions, technology sharing, production and management modes, and capital mobility between cities across territorial boundaries.

As Böckerman and Lehto (2006) argued, M\&A projects involve value evaluation, monitoring, sharing assets and synergy operations and thereby as Rodríguez-Pose and Zademach (2003) found, M\&A deals are concentrated in global and globalising city regions, driving regional economies as an outcome. M\&A projects represent capital mobility between network enterprises and are important as generators of regional aggregate capital flows and spillovers. M\&A deals have grown continuously in the MYR region since the year 2003, peaking in 2010 and followed by a recession period until 2014. Social Network Analysis from which Interlocking Office Network analysis derives (Smith and Timberlake, 1995; Taylor 2001, 2004) was the selected method used for analysis since it does not rely on data on any specific sector and can investigate any city network relations constructed by direct flows. The approach can be adapted to illustrate complex multi-directional flows and can also be used to identify specific city functions not quantified in the Interlocking Office Network model.

M\&A data from 2003 to 2014 from the Zephyr database (Bureau von Dijk, 2015) which is the most comprehensive source on worldwide M\&A deals and is updated hourly, were used to establish the 
Mid-Yangtze River inter-city network, based on source and target companies, and source and target cities, deal types and values, and industrial classifications including manufacturing and APS sectors (Property Services, Banking, and Insurance \& Financial Services). In total, 1238 M\&A deals from 2003 to 2014 involved 42 cities in the region, forming a city-by-city network. All deals are valued above 1 million Chinese Yen and deal types include mergers, acquisitions, minority stake ( $>2$ per cent), and capital increase. The key criterion for inclusion of deals in the analysis was that they involve the transfer of a business and operations in the M\&A process.

In conclusion, since the global cities literature pointed increasingly to the significance of network enterprises in the construction of inter-city capital flows and networks (Friedmann, 1986; Sassen, 1991, Castells, 1996), investigation of the networks constructed by economic agents and circuits of inter-city flows using data relevant for a city region's development stage in economic globalisation, has become an important research area for shedding light on functional and spatial development patterns, and thereby polycentrism in the South East England and Mid-Yangtze River region cases.

City Region Emergence Processes in Network Space - Morphological or Functional Polycentrism? Level 1

The South East England city region is dominated by Greater London which is $25 \mathrm{~km}$ in radius despite being bounded by a 'green belt' that has been largely successfully contained the expansion of the metropolitan area since the mid-twentieth century. London's population of over nine million represents just under half the city region population. However South East England is one of the densest city regions in North West Europe. Outside the London boundary, 50 smaller cities and towns ranging in size from 79,000 to 600,000 in population have shown consistent and strong service sector economic growth in the last half century. South East England employment shrank in the 1980s especially in London, but rebounded in the 1990s, growing by 33 per cent with nearly a 25 per cent increase in London. Employment is heavily concentrated in the service sector, especially the APS sector; 80 per cent of all employment is in services, with banking and financial services representing more than a quarter. Significantly, financial and linked business services are strongly represented in cities and towns outside London, especially to the west of the city region.

Relative to developed South East England, the Mid-Yangtze River city region has only recently become the location for large-scale urbanisation and economic development. Since economic reform and the introduction of 'open door' policy in China which allowed its integration in the capitalist world economy, the national urbanisation rate has boomed, rising from 18.62 per cent in 1979 to 54.41 per cent in 2014. As recently as 2016, Wuhan in the Mid-Yangtze River city region became the only city in central China with a population exceeding 10 million. With its strong manufacturing industrial base, the city region represents more than half of central China's economic activity against 
several economic indicators: 53.19 per cent GDP, 55.05 per cent fixed asset investment and 51.22 per cent fiscal revenue (NBS, 2014 ${ }^{3}$ ). In contrast to the national decline in growth since the 2008 global economic crisis, the city region's economic development has maintained a double-digit growth rate (NBS, 2014). However, the service economy remains relatively undeveloped in comparison with that of South East England, especially in APS. Despite these stage of development differences, both case studies have targeted analysis on inter-city flows associated with the activities of economic network enterprises in order to shed light on city region functional and associated spatial development patterns. The results therefore reveal the extent to which the regions are characterised by either functional or morphological polycentrism.

\section{Learning from the South East England case Level 2}

Important for addressing the question, can attention to city network space, functions and flows usefully inform conceptualisation of polycentrism, the European research identified two distinctive city region development processes: Process A - 'mega-city region economic expansion' and Process B - 'mega-city regions of proximate cities' (Taylor and Pain, 2007; Pain, 2008a).

Process A is distinguished by a polycentric functional pattern associated with multi-sector APS clusters across South East England, which generate Jacobsean economic enveloping and upgrading of an extensive city region surrounding London. London's high multi-sector global APS network connectivity is transmitted across the larger space forming a functionally interconnected city region with smaller centres that are growing economically at a similar rate to London. Jacobs claimed that city economic forces can be very powerful and in the case of South East England, process A involves a simultaneous diffusion of markets, jobs, production, technologies and capital across the city region space. Process A contrasts with process B which is distinguished by morphological polycentricity in which cities are of a similar size but they are characterised by APS sectoral specialization, and a less globally networked city region. Less globally connected first cities are failing to spread their prosperity to a wider regional scale. Jacobs (1984) argued that city regions are not defined by natural boundaries but instead they are the artefacts of cities whose economic energy dictates their boundaries. The South East England case demonstrates that in a globalized economy, city energy comes from global city networks and it can be spread through global cities across an extensive area, producing functional complementarities between cities and towns of different sizes, and functional polycentricity as an outcome.

${ }^{3}$ The National Bureau of Statistics (NBS) is the only agency authorised by the State Council of China to collect statistical data and economic accounting in national scope. 
Related to the distinction between the two city region development processes identified, a finding from the research relevant for the question of how polycentrism should inform planning policies in the context of city regions that are at different stages of connecting to economic globalisation, was that the morphologically polycentric city regions studied did not benefit from a balanced distribution of economic activities. Interviews with APS firms in offices across the eight city regions revealed that office networks at the regional scale are not necessarily representative of actual high value information and capital flows between centres (Pain and Hall, 2008). All eight city regions, whether morphologically or functionally polycentric, were found to have only one city with intense crossborder global flows, illustrating that city functional primacy vs city functional polycentricity is invisible if only morphology is considered. For example, the Rhine-Ruhr was the most morphologically polycentric city region studied but this spatial pattern does not translate to a functional pattern and functional polycentricity. Similarly, in South East England, city region functional polycentricity associated with London's supreme global APS network connectivity belies its morphological description in European strategy as a monocentric urban region due to London's size. Nevertheless, the South East England geographical distribution of networked, economically buoyant centres beyond London has a distinct western orientation. Former Government 'Growth Areas' 'Milton Keynes-South Midlands' and 'London-Stansted-Cambridge' to the north-east of London, contain important networked multi-sector APS clusters which give them connectivity at different spatial scales. However, the 'Thames Gateway' to the East and 'Ashford' to the South East of London, remain relatively disconnected from APS network activities and connectivity. Buoyant economic centres include the 'Reading-Thames Valley Corridor' to the west of London which has the second highest GVA in England to London. Therefore, the study found that morphological polycentricity cannot reveal the underlying economic functionality and complementarities of city regions. Attention to city network space, functions and flows is needed to inform conceptualisation of polycentrism, demonstrating the need for more network analysis. The paradigm of city region polycentrism required to inform policy, is the combination of functionality and complementarity.

Against this developed world research backdrop, what can be learned about the concept of polycentrism from a recently emergent city region that is undergoing political economy change as China is opening up to the capitalist economy and economic globalisation at a rapid pace?

\section{Learning from the Mid-Yangtze River region case Level 2}

The results from the Mid-Yangtze River case show that the number of M\&A deals in the city region has been increasing between 2006 and 2014 and is interconnecting its cities gradually. The city network patterns in 2006 and 2014 illustrate distinctive phases during the network evolution process. In the endogenous phase, most inter-city network links have been associated with city region primary cities, Wuhan, Changsha and Nanchang, while there have been relatively few links between medium 
size cities and there have been several isolated cities located at the geographical periphery of the city region. However, network links between medium size cities have been increasing over time and the number of isolated cities has been decreasing during the endogenous phase even though the process of change has been evolving slowly. The final pattern of the city network by the year 2014 showed that the whole city region had become more integrated than before, characterised by a transition from a centralised network to a balanced city region network. Thus, Mid-Yangtze city network development is moving from a first endogenous phase which is characterised by the self-growth of cities to a second interactive phase that is characterised by more multidimensional and complex inter-city relations (see also Asheim and Gertler, 2005).

In addition, it is noted that although Wuhan is the most outperforming city in the region, its leading role is challenged by Changsha and Nanchang, which indicates a pattern of polycentricity to some extent. Additional investigation of the inter-city network included other city characteristics ranging from global network to individual city network attributes using network centrality analysis. The findings revealed that having similar sectoral attributes is not required to initiate city interactions. Large cities with more central network positions and more intensive network links are more heterogeneous. With the evolution of the network, the economic functions and network positions of cities are changing. For example, Changsha, which was originally an indigenous hub for the Hunan sub-region, has evolved into a leading city for the whole city region with the development of more external functional connections to cities in other sub-regions. Thus, the pattern of network centrality is shifting and is dependent on 'when and at what particular relations we look' (Timberlake, 2010, p.2). In conclusion, it is found that Mid-Yangtze River city region is a dynamic complex centralised network space full of multidirectional and transboundary flows where network power is concentrated on primary cities and distributed across distinctive network functions.

Although the Interlocking Network approach that is based on the office functions of APS firms was not adopted to estimate the city region's network connectivity due to its stage of economic development, APS sectors are highly representative of the knowledge economy and are thereby important for the future city region economic upgrading (the Jacobsean process A). The reciprocal association of manufacturing and APS sectors is expected to be the key to accomplishing economic transition in inland areas of China, and the Mid-Yangtze River city region is expected to play a key part in this transition. APS sectors provide specialised services to producers, which add value to manufacturing production which is the foundation service market which will facilitate APS sector development in the city region and in China as a whole, therefore, APS spatial agglomeration patterns and their correlations with manufacturing were examined. A Pearson correlation matrix and Principle Components Analysis showed that manufacturing and APS sectors (Logistics and 
Telecommunications, Financial Services and Banking, Real Estate and Research Services) are correlated positively at significance level.

In conclusion, based on the evidence from network analysis using data on M\&A capital flows, the city region is not characterised simply by the economic functional expansion process $B$ identified in Europe: 'mega-city regions of proximate cities'. There is evidence of an early stage Jacobsean 'megacity region economic expansion' (process A) and emergent functional polycentrism as an outcome. Through M\&A deals, capital (the main driver of Chinese economic growth) is flowing from primary to secondary cities stimulating an increase in APS activity beyond primary cities. However, in the Mid-Yangtze River region inter-city network, a high proportion of deals is initiated in primary cities, particularly for high-value deals above 10 million yen, and big deals are transacted by localized APS services located in those primary cities (Taylor et al., 2003). This finding resonates with empirical work by Yang and Yeh (2013) in which they found that in contrast to manufacturing activities, APS firms are more concentrated in Chinese high-tier cities. In contrast, the city network links examined in South East England represent actual relations and information flows between APS actors and offices located in cities and towns outside London. They are therefore distinct from Mid-Yangtze River city region network links represented by M\&A capital flows assisted by APS actors who are concentrated in primate cities. Nevertheless, APS assisted advances in manufacturing production could in future potentially spur the concentration and dispersion of APS offices in the city region to meet increasing market demand for specialised financial and business services. This dual concentration and dispersion space economy dynamic first noted by Sassen (1991), could potentially advance city region economic expansion process A and associated functional polycentrism qualitatively. Next we turn to consider the two questions posed at the start of the paper.

\section{Polycentrism Embedded in Inter-city Flow Networks and Policy Implications Level 1}

Firstly, based on the two case studies, what conclusions can be drawn about whether attention to city network space, functions and flows can usefully inform conceptualisation of polycentrism?

The findings from both cases illustrate that distinctions between city region expansion processes revealed by network analysis are relevant for polycentrism conceptualisation. Network space is dynamic, heterogeneous and complex in nature (Baum et al., 2000) making networks, functions, flows and complementarities critical for the meaning of city region polycentrism. Increasingly, the relevant focus for policy is no longer the city; it is the city region (Kloosterman and Musterd, 2001, p. 627) which is generated through Castells' space of flows and is highly networked through city network links at different scales (Jonas, 2011). Instead of focusing on morphological polycentricity, network thinking should be highlighted to shed light on functional polycentrism in the process of city region development. The case studies demonstrate that the city networks created by cross-territorial 
economic activities (APS activities and M\&A deals) are intrinsically embedded in city regions. Associated with deepening globalisation, these urban interactions engage advanced productive factors (human resources, knowledge and information) intangibly, representing a transformation from a twodimensional 'place' to a three-dimensional 'space'. These advanced interurban flows are no longer tied to Tobler's first law of geography but overcome spatial constraints at low cost, facilitated by modern transportation and information technology. Consequently, circulating interurban flows construct a complex network space in which cities have different roles and functions that give rise to complementary inter-city relationships and to functional polycentricity at a city region scale as an outcome. We conclude that attention to city network space, functions and flows can usefully inform the conceptualisation of regional polycentrism.

Second, how should the concept of polycentrism inform planning policies in the context of city regions that are at different stages of connecting to economic globalisation? Corresponding implications of the results from the investigation of network space in the two city regions are that policies should be oriented to strategic network planning underpinned by cross-territorial cooperation as opposed to competition. Active institutional networks and collaboration are vital for the management of complex emerging regional spaces of flows that do not map onto established administrative areas and territorial boundaries. The multi-directionality of inter-city flows identified in both cases, points to the need for up-to-date network flow-tracking systems. Furthermore, such systems need to be populated by data that are relevant to specific city region economic development stages in order to assist strategic planning and to inform territorial cooperation based on otherwise invisible city economic complementarities. Such systems could potentially more accurately pinpoint economic expansion processes at a granular level in different city regions in Europe than has previously been possible, as well as in other parts of the world. Policy aimed at city region rebalancing based purely on a morphological polycentric pattern contradicts actual inter-city flows generated in economic network space. In addition, intertwined with sectoral heterogeneity as an important characteristic of city interaction, network flows and functional polycentricity, the assets and capital that are embedded in urban locales will be important for network development. The findings from the case studies reviewed in this paper therefore demonstrate that by taking into account the congruence of geo-space and network space in economic globalisation, the concept of polycentrism can better inform planning policies for city regions that are at different development stages. Given the different development stages of city regions worldwide, policies aiming to rebalance the spatial distribution of economic activity also need to take into account the characteristics of dominant city region industries. For manufacturing-dominated regions, rebalancing should give weight to the promotion of city interlinkages in chained value-adding processes while, for APS-dominated regions, policies should be oriented towards recognition of and support for horizontal interactions across high value-added APS sectors. We conclude that the concept of polycentrism can only have relevance for 
policy to foster economic rebalancing when a theory of city region space as an artefact of city networks is taken into account and an appropriate network approach is applied in analysis.

\section{References}

Aghion, P. and Howitt, P. (1998) Market structure and the growth process. Review of Economic Dynamics, 1(1), 276-305.

Aharoni, Y. and Nachum, L. (2002) Globalisation of services: Some implications for theory and practice. London: Routledge.

Baum, J. A., Calabrese, T. and Silverman B. S. (2000) Don't go it alone: Alliance network composition and startups' performance in Canadian biotechnology. Strategic Management Journal, 267-294.

Bathelt, H., Malmberg, A. and Maskell, P. (2004) Clusters and knowledge: local buzz, global pipelines and the process of knowledge creation. Progress in Human Geography, 28(1), 31-56.

Bathelt, H. and Taylor, M. (2002) Clusters, power and place: inequality and local growth in timespace. Geografiska Annaler: Series B, Human Geography, 84(2), 93-109.

Beaverstock, J. V., Smith, R. G., and Taylor, P. J. (1999) A roster of world cities. Cities, 16(6), 445458.

Bel, G. and Fageda, X. (2008) Getting there fast: globalisation, intercontinental flights and location of headquarters. Journal of Economic Geography, 8(4), 471-495.

Berry, B. J. (1964) Cities as systems within systems of cities. Papers in Regional Science, 13(1), 147163.

Böckerman, P. and Lehto, E. (2006) Geography of domestic mergers and acquisitions (M\&As): Evidence from matched firm-level data. Regional Studies, 40(8), 847-860.

Boschma, R. (2004) Competitiveness of regions from an evolutionary perspective. Regional Studies, 38(9), 1001-1014.

Breschi, S. and Lenzi, C. (2014) The returns of external linkages: the role of gatekeepers for the renewal and expansion of US cities' knowledge base, 1990-2004. Papers in Evolutionary Economic Geography, 14(14). 
Bureau von Dijk (2015) Zephyr M\&A Database. Retrieved from https://zephyr.bvdinfo.com/version20171030/ZephyrNeo.HomePage.serv?_CID=1\&context=BFX1F1ZSP3L0NJH.

Burt, R. S. (2009) Structural holes: The social structure of competition. Boston, MA: Harvard University Press.

Button, K., Lall, S., Stough, R. and Trice, M. (1999) High-technology employment and hub airports. Journal of Air Transport Management, 5(1), 53-59.

Castells, M. (1996) The Network Society (Vol. 469). Oxford: Blackwell.

Castells, M. (1999) Grassrooting the space of flows. Urban Geography, 20(4), 294-302.

Christaller, W. (1966) Central places in southern Germany. Jena: Fischer.

Cochrane, A. and Pain, K. (2000) A Globalising Society? in Held, D. (ed.) A Globalising World. London: Routledge, pp. 5-45.

Coe, N. M. and Yeung, H. W.-C. (2015) Global production networks: Theorising economic development in an interconnected world. Oxford: Oxford University Press.

Davoudi S. (2003) Polycentricity in European spatial planning: from an analytical to a normative agenda. European Planning Studies, 11, 979-999.

Derudder, B., Taylor, P., Ni, P., De Vos, A., Hoyler, M., Hanssens, H., Bassens, D., Huang, J., Witlox, F. and Shen, W. (2010) Pathways of Change: Shifting Connectivities in the World City Network, 2000-08. Urban Studies, 47(9), 1861-1877.

Derudder, B. and Taylor, P. (2016) Change in the world city network, 2000-2012. The Professional Geographer, 68(4), 624-637.

Duhr S. and Nadin V. (2005) Spatial Vision Study No. 1 Final Report. 30 June 2005, NorthWest Europe INTERREG IIIB Spatial Vision Working Group. Bristol: University of the West of England.

Duranton, G. and Puga, D. (2001) Nursery cities: Urban diversity, process innovation, and the life cycle of products. American Economic Review, 1454-1477.

European Commission (CEC) (1999) ESDP: European Spatial Development Perspective: Towards Balanced and Sustainable Development of the Territory of the European Union. Brussels: European Commission. 
European Commission (CEC) (2004) Facing the Challenge: The Lisbon Strategy for Growth and Employment, Report from the High Level Group chaired by Wim Kok, November 2004. Brussels: Commission of the European Communities.

European Commission (CEC) (2005) Cohesion Policy in Support of Growth and Jobs: Community Strategic Guidelines, 2007-2013. Brussels: Commission of the European

Communities.

European Commission (CEC) (2008) Green Paper on Territorial Cohesion - Turning Territorial Diversity into Strength. Brussels: Commission of the European Communities.

European Commission (CEC) (2009) Lisbon Treaty (unconsolidated). Brussels: Commission of the European Communities.

European Commission (CEC) (2012) Cohesion Policy 2014-2020, Investing in Growth and Jobs. Brussels: Commission of the European Communities.

European Council (EC) (2000) Presidency Conclusions, Lisbon European Council, 23 and 24 March 2000. Electonic, available at http://www.

Freeman, L. (2004) The Development of Social Network Analysis: A Study in the Sociology of Science. North Charleston, SC: BookSurge.

Friedmann, J. (1986) The world city hypothesis. Development and Change, 17(1), 69-83.

Friedmann, J. (2005). Globalisation and the emerging culture of planning. Progress in Planning, 64(3), 183-234.

Fujita, M., Krugman, P. R. and Venables, A. (2001) The Spatial Economy: Cities, Regions, and International Trade. Cambridge, MA: MIT press.

Grubesic, T. H., Matisziw, T. C. and Zook, M. A. (2008) Global airline networks and nodal regions. GeoJournal, 71(1), 53-66.

Hakansson, H. (1987) Industrial Technological Development: A Network Approach. London: Croom Helm. 
Halbert L., Pain K. and Thierstein A. (2006) European polycentricity and emerging mega-city regions: 'one size fits all' policy? Built Environment, 32, 206-218.

Hall, P. and Pain, K. (2006) The Polycentric Metropolis: Learning from mega-city regions in Europe. London: Routledge.

Harrington, J. W. and Campbell, H. S. (1997) The suburbanisation of producer service employment. Growth and Change, 28(3), 335-359.

Harrington, J. W. and Daniels, P. W. (2006) Knowledge-based services, internationalisation and regional development. Aldershot: Ashgate.

Harris, C. D. and Ullman, E. L. (1945) The nature of cities. The Annals of the American Academy of Political and Social Science, 242, 7-17.

Hoyler, M. and K. Pain (2001) London and Frankfurt as World Cities: Changing Local- global Relations', in A. Mayr, M. Meurer and J. Vogt (eds.), Stadt und Region: Dynamik von Lebenswelten. Leipzig: Deutsche Gesellschaft für Geographie, pp. 76-87.

Huggins, R. (2010) Forms of Network Resource: Knowledge Access and the Role of Inter-Firm Networks. International Journal of Management Reviews, 12(3), 335-352.

Huggins, R. and Johnston, A. (2010) Knowledge flow and inter-firm networks: The influence of network resources, spatial proximity and firm size. Entrepreneurship \& Regional Development, 22(5), 457-484.

Huggins, R. and Thompson, P. (2015) Entrepreneurship, innovation and regional growth: a network theory. Small Business Economics, 45(1), 103-128.

Jacobs, J. (1984) Cities and the wealth of nations: Principles of economic life. New York, NY: Random House.

Jonas, A. (2011) Scales and Networks, in J. A. Agnew and S. Duncan (eds), The Wiley- Blackwell Companion to Human Geography, Oxford: Wiley-Blackwell, pp. 387-483.

Kloosterman, R. C. and Musterd, S. (2001) The polycentric urban region: towards a research agenda. Urban Studies, 38(4), 623-633. 
Kramer, J.-P., Marinelli, E., Iammarino, S. and Diez, J. R. (2011) Intangible assets as drivers of innovation: Empirical evidence on multinational enterprises in German and UK regional systems of innovation. Technovation, 31(9), 447-458.

Krugman, P. (1991). Geography and Trade. Cambridge, MA: MIT Press.

Lizieri, C. and Pain, K. (2014) International office investment in global cities: the production of financial space and systemic risk. Regional Studies, 48(3), 439-455.

Mahroum, S., Huggins, R., Clayton, N., Pain, K. and Taylor, P. (2008) Innovation by adoption: measuring and mapping absorptive capacity in UK nations and regions. London: National Endowment for Science, Technology and the Arts (NESTA).

Markusen, A. (2003) Fuzzy concepts, scanty evidence, policy distance: the case for rigour and policy relevance in critical regional studies. Regional Studies, 37(6-7), 701-717.

Massey, D. B., Allen, J. and Pile, S. (1999) City Worlds. London: Routledge.

Meijers, E. (2007) From central place to network model: theory and evidence of a paradigm change. Tijdschrift voor economische en sociale geografie, 98(2), 245-259.

Miller, H. J. (2004) Tobler's first law and spatial analysis. Annals of the Association of American Geographers, 94(2), 284-289.

Moulaert, F. and Daniels, P. W. (1991) Advanced producer services: beyond the micro-economics of production. London: Belhaven Press.

National Bureau of Statistics, China (2014) The National Bureau of Statistics of the People's Republic of China. Retrieved from http://www.stats.gov.cn/english/

Newman, M. E. (2006) Modularity and community structure in networks. Proceedings of the National Academy of Sciences, 103(23), 8577-8582.

Nicolini, D., Gherardi, S. and Yanow, D. (2003) Knowing in organisations: a practice-based approach. New York, NY: ME Sharpe.

Nordlund, C. (2004) A critical comment on the Taylor approach for measuring world city interlock linkages. Geographical Analysis, 36(3), 290-296.

O’Brien, R. (1992) Global Financial Integration: The End of Geography. London: Pinter. 
Ohmae, K. (1990) The Borderless World: Power and Strategy in the Interlinked Economy. London: Harper Collins.

Ohmae, K. (1995) The End of the Nation State: The Rise of Regional Economies. London: Harper Collins.

Pain, K. (2008) Examining 'core-periphery' relationships in a global city-region: the case of London and South East England. Regional Studies, 42(8), 1161-1172.

Pain, K. (2012) Spatial transformations of cities: global city-region? Mega-city region? In B.

Derudder, M. Hoyler, P. Taylor, \& F. Witlox (eds.), International Handbook of Globalisation and World Cities, pp. 83-93. Cheltenham: Edward Elgar.

Pain, K. and Hall, P. (2008) Informational quantity versus informational quality: the perils of navigating the space of flows. Regional Studies, 42(8), 1065-1077.

Pain, K. and Van Hamme, G. (2014) Changing Urban and Regional Relations in a Globalising World: Europe as a Global Macro-Region. Cheltenham: Edward Elgar.

Powell, W. W., Koput, K. W. and Smith-Doerr, L. (1996) Interorganisational collaboration and the locus of innovation: networks of learning in biotechnology. Administrative Science Quarterly, 116145.

Puga, D. (1999) The rise and fall of regional inequalities. European Economic Review, 43(2), 303334.

Redding, S. and Venables, A. J. (2004) Economic geography and international inequality. Journal of International Economics, 62(1), 53-82.

Rodríguez-Pose, A. and Zademach, H.-M. (2003) Rising metropolis: the geography of mergers and acquisitions in Germany. Urban Studies, 40(10), 1895-1923.

Rozenblat, C. (2010) Opening the black box of agglomeration economies for measuring cities' competitiveness through international firm networks. Urban Studies, 47(13), 2841-65.

Rozenblat, C. and Pflieger, G. (2010) Introduction. Urban networks and network theory: The city as the connector of multiple networks. Urban Studies, 47(13), 2723-35. 
Sassen, S. (1991) The Global City: New York, London, Tokyo. Princeton, NJ: Princeton University Press.

Scott, A. (2001a) Global City-Regions: Trends, Theory, Policy. Oxford: Oxford University Press.

Scott, A. J. (2001b) Globalisation and the rise of city-regions. European Planning Studies, 9(7), 813826.

Smith, D. A. and Timberlake, M. (1995) Cities in global matrices: toward mapping the worldsystem's city system. World Cities in a World-System, 79-97.

Smith, H. L., Romeo, S. and Virahsawmy, M. (2012) Business and professional networks: scope and outcomes in Oxfordshire. Environment and Planning A, 44(8), 1801-1818.

Taylor, P. J. (2001) Specification of the world city network. Geographical Analysis, 33(2), 181-194.

Taylor, P. J. (2004) World City Network: A Global Urban Analysis. London: Routledge.

Taylor, P. J. (2009) Urban economics in thrall to Christaller: A misguided search for city hierarchies in external urban relations. Environment \& Planning A, 41, 2550 - 2555.

Taylor, P., Beaverstock, J., Cook, G., Pandit, N., Pain, K. and Greenwood, H. (2003) Financial Services Clustering and its Significance for London. London: Corporation of London.

Taylor, P. J., Catalano, G. and Walker, D. R. (2002) Exploratory analysis of the world city network. Urban Studies, 39(13), 2377-2394.

Taylor, P. J., Hoyler, M. and Verbruggen, R. (2010) External urban relational process: introducing central flow theory to complement central place theory. Urban Studies, 47(13), 2803-2818.

Taylor, P. J. and Pain, K. (2007) Polycentric mega-city regions: Exploratory research from Western Europe. In P. Todorovich (Ed.), The Healdsburg Research Seminar on Megaregions (pp. 59-66). New York: Lincoln Institute of Land Policy and Regional Plan Association.

Timberlake, M. (2010) The Kaleidoscoping World City Networks: How Research Locates Cities in Global Systems of Cities. Paper presented at the World Congress of the International Sociological Association, Gothenburg, Sweden, July.

Tobler, W. R. (1970) A computer movie simulating urban growth in the Detroit region. Economic Geography, 46(sup1), 234-240. 
Van Oort, F., Burger, M. and Raspe, O. (2010) On the economic foundation of the urban network paradigm: spatial integration, functional integration and economic complementarities within the Dutch Randstad. Urban Studies, 47(4), 725-748.

Wallerstein, I. (1974) The Modern World-System, Vol.1: Capitalist Agriculture and the Origins of the European World-Economy in the Sixteenth Century, New York/London: Academic Press.

Watts, D. J. (1999) Small worlds: the dynamics of networks between order and randomness.

Princeton, NJ: Princeton University Press.

Wood, P. A. (1991) Flexible accumulation and the rise of business services. Transactions of the Institute of British Geographers, 160-172.

Yang, F. F. and Yeh, A. G. (2013) Spatial development of producer services in the Chinese urban system. Environment and Planning A, 45(1), 159-179. . 